\title{
The Graphene Oxide Spincoating Optimalization by Planned Experiment
}

Radim Zahradicek ${ }^{1}$,Tomas Prokes ${ }^{2}$,Libor Benes ${ }^{3}$

${ }^{1}$ The Faculty of Electrical Engineering and Communication, Brno University of Technology, Technická 3058/10, 616 00 Brno. Czech Republic. E-mail: zahradnicek@vutbr.cz

${ }^{2}$ The Faculty of Mechanical Engineering, Brno University of Technology, Technická 2, 61669 Brno. Czech Republic. Email: y145185@stud.fme.vutbr.cz

${ }^{3}$ Faculty of Production Technology and Management, J. E. Purkyne University in Usti nad Labem. Pasteurova 3334/7, 40001 Usti nad Labem. Czech Republic. E-mail: benes@fvtm.ujep.cz

Spin coating is basic method for preparation of thin polymer resist layer (polycarbonate) or colloidal solution (grapheme oxide in alcohol). This method main benefits are speed of preparation and the possibility of tuning final coating of silicon sample by variations of parameters such as the speed of rotation, time and the amount of the solution. To find out the exact graphene oxide layer spin coating process a planned experiment was designed. The greatest coverage of the silicon sample grapheme was obtained by studying the data obtained from electron microscopy (SEM) and light microscopy (LM) of the spin coating input conditions

Keywords: Graphene oxide, spin coating, Design of Experiment, Analysis of Variance, response surface.

\section{Acknowledgement}

This work was carried out with the support of core facilities of CEITEC-Central European Institute of Technology under CEITEC - open access project, ID number LM2011020, funded by Ministry of Education, Youth and Sports of the Czech Republic under the activity Projects of major infrastructures for research, development and innovations.

\section{References}

[1] BOLOTIN, K. I., ET AL. (2008). Ultrahigh electron mobility in suspended graphene. Solid State Communications, Vol. 146, No. 9, pp. 351-355.

[2] SZE, S. M., KWOK, NG. (2006). Physics of semiconductor devices. 3rd ed.Wiley-Interscience, Hoboken, N.J.

[3] BERNS, H., THEISEN, W. (2008). Ferrous materials: steel and cast iron.Springer, Berlin.

[4] LEE, C., ET AL. (2008).Measurement of the elastic properties and intrinsic strength of monolayer graphene. Science, Vol. 321, No. 5887, pp. 385-388.

[5] Yavuz, S., ET AL.(2016). Graphene oxide as a p-dopant and an anti-reflection coating layer, in graphene/silicon solar cells. Nanoscale, Vol. 8, No. 12, pp. 6473-6478.

[6] NOVOSELOV, K., ET AL. (2012). A roadmap for graphene. Nature, Vol. 490 No. 7419, pp. $192-200$.

[7] CHEN, X., ET AL. (2015). Large area CVD growth of graphene. Synthetic Metals, Vol. 210, pp. 95-108.

[8] HUMMERS JR, W. S., OFFEMAN, R. E. (1958). Preparation of graphitic oxide. Journal of the American Chemical Society, Vol. 80, No. 6, pp. 1339-1339.

[9] MOURALOVA, K., KOVAR, J. (2015). Quality of dimensions accurancy of components after WEDM depending on the heat treatment. MM Science Journal, pp. 790-793.

[10] MOURALOVA, K., ET AL. (2016). Analyzing the surface layer after WEDM depending on the parameters of a machine for the $16 \mathrm{MnCr} 5$ steel. MEASUREMENT, Journal of the International Measurement Confederation (IMEKO), Vol. 94, pp. 771-779,.

[11] MOURALOVA, K., KOVAR, J., KLAKURKOVA, L. (2017) Evaluation of total hight of profile of the surface machined by WEDM. MM Science Journal, No. 1, pp. 1674-1678.

[12] MOURALOVA, K., ET AL. (2017). Experimental evaluation of the quality of surface after WEDM for steel X210CR12. MM Science Journal, Vol. 2, pp. 1778-1782.

[13] MOURALOVA, K., ET AL. (2017). Quality of aluminium alloy surface after WEDM. MM Science Journal, 2017, No. 1, pp. 1679-1682.

[14] GUO, Y., ET AL. (2010). General route toward patterning of graphene oxide by a combination of wettability modulation and spin-coating. ACS nano, Vol. 4, No. 10, pp. 5749-5754. 